\title{
Immunohistochemical changes in the jejunum in first degree relatives of patients with coeliac disease and the coeliac disease marker DQ genes. HLA class II antigen expression, interleukin-2 receptor positive cells and dividing crypt cells
}

\author{
K Holm, E Savilahti, S Koskimies, V Lipsanen, M Mäki
}

\begin{abstract}
The staining of HLA class II antigens, the presence of cells positive for interleukin-2 receptors, the proportion of crypt cells in mitosis in the jejunal biopsy specimens, and the dose of coeliac disease marker HLA-DQ genes were studied in 75 healthy family members of coeliac disease patients. Eleven had silent coeliac disease; in the rest the morphology of the jejunum was normal. In the specimens from family members, staining of epithelial cells with HLA-DP and -DR antibodies was more widely distributed and stronger than in those from 19 controls. Interleukin-2 receptor + cells were seen in the epithelium of all eight specimens from subjects with silent coeliac disease, and also in 24 morphologically normal specimens from family members, but not in the 19 control specimens. The proportion of crypt cells in mitosis was increased only in the specimens from the subjects with silent coeliac disease. The staining intensity of the epithelial cells with HLA-DP and -DR antibodies, the presence of interleukin- 2 receptor + cells and the percentage of crypt cells in mitosis were significantly associated with the number of coeliac disease marker DQB genes. Many family members of patients with coeliac disease have signs of inflammation even in morphologically normal jejunum; these inflammatory changes together with coeliac disease marker DQ genes may point to latent disease in these subjects.
\end{abstract}

(Gut 1994; 35: 55-60)

Department of Clinical Sciences, University of Tampere, Finland K Holm

M Mäki

Children's Hospital, University of Helsinki, Finland

E Savilahti

Finnish Red Cross Blood Transfusion Service, Helsinki, Finland

S Koskimies

V Lipsanen

Correspondence to:

Dr E Savilahti, Children's Hospital, University of Helsinki, Stenbäckinkatu 11 SF-00290 Helsinki, Finland.

Accepted for publication 26 May 1993 gluten ingestion. ${ }^{7}$ In patients with dermatitis herpetiformis and a normal jejunal structure, latent coeliac disease may be shown by the activation of the local immunoglobulin producing system in the gut ${ }^{89}$ and they, like many relatives of coeliac disease patients, may have increased numbers of intraepithelial lymphocytes. ${ }^{10-12}$ We have shown earlier that in family members of coeliac disease patients the density of both $\alpha / \beta$ and $\gamma / \delta \mathrm{T}$ cell receptor bearing cells is frequently higher than in controls even when the villous structure is quite normal. The increase in the density of $\gamma / \delta+T$ cells was linked with the coeliac disease marker (CDM) DQ genes ${ }^{13}$ and one patient with a high density of $\gamma / \delta$ T cells had a clinical relapse of coeliac disease. ${ }^{14}$ In this study we examined the jejunal biopsy specimens of 75 healthy cases among the same family members of coeliac disease patients, looking for HLA class II antigen expression and the presence of cells positive for the interleukin-2 receptor (CD25) in the epithelium of the jejunum, and quantified the dividing cells in the crypts. These measurements, probably reflecting the activity of immune inflammation, were compared with the dose of CDM DQ genes.

\section{Materials and methods}

PATIENTS

Altogether 122 of 148 healthy first degree relatives of coeliac disease patients had a biopsy. ${ }^{15}$ We studied biopsy specimens from 75 unselected relatives, whose blood samples were available for analysis of HLA class II genes at the DNA level. These healthy relatives had no signs of malabsorption and had not experienced the typical abdominal symptoms. The healthy family members had been on a normal gluten containing diet and were even encouraged to eat at least 10 grams of gluten per day three months before evaluation.

Biopsy specimens from family members were taken with a capsule from the proximal jejunum. Altogether 64 of 75 jejunal biopsy specimens were evaluated as having normal morphology. The remaining 11 healthy relatives were found to have villous atrophy with crypt hyperplasia. Biopsy specimens taken during a subsequent gluten free diet period showed normalisation of the jejunal mucosa in every one of these patients. They thus had silent coeliac disease. 
CONTROLS

Specimens taken from the distal duodenum or proximal jejunum of 19 adult patients having gastroscopy because of dyspepsia and with no coeliac disease relatives served as controls. In these specimens, villous morphology was normal with a villous height/crypt depth ratio of $>3$.

The study protocol was approved by the ethical committee of the University Hospital of Tampere.

\section{IMMUNOHISTOCHEMICAL STAINING}

Each jejunal biopsy specimen was divided into two parts; one part was processed by routine histological methods. The other part of the fresh biopsy specimen was embedded in OCT, frozen with liquid nitrogen, sealed in an airtight plastic bag, and kept at $-70^{\circ} \mathrm{C}$ until cut. Serial cryostat sections cut at $5 \mu$ thickness were fixed in acetone for 10 minutes, then in chloroform for 30 minutes, and washed three times in TRIS buffer, $\mathrm{pH} 7 \cdot 4$. The buffer was removed and the sections were covered with a dilution of monoclonal antibodies in TRIS buffer for one hour. Endogenous peroxidase was blocked by incubation in $0.5 \%$ peroxide for 30 minutes. A Vectastain Elite $\mathrm{ABC}$ kit (PK-6102, Vectro Laboratories, Burlinghame, $\mathrm{Ca}$, USA) was used to show the binding of the monoclonal antibodies in accordance with the manufacturer's instructions. Interleukin- 2 receptor staining was also developed by triple incubation with the monoclonal antibody followed by alkaline phosphatase antialkaline phosphatase antiserum. The phosphatase was visualised with a fast red reagent. ${ }^{16}$

The coded specimens were evaluated by $\mathrm{K}$ Holm without knowledge of the background of the specimen. The numbers of stained cells were counted with a light microscope through a calibrated graticule at $\times 1000$ magnification. Staining of epithelial cells with antibodies to HLA class II antigens was graded from 0 to 3 . Evaluation was based on the intensity of staining of the cells, its distribution over the cell membranes, and the proportion of the villi and crypts having positively stained cells. If positive epithelial cells were seen in the crypts, the intensity was always graded as 3 .

Of the surface and crypt epithelia, 20 to 30 fields $(1-1.5 \mathrm{~mm})$ were examined for the presence of $\mathrm{CD} 25$ + round cells. Ki67 positive cells in the crypts were calculated as percentages of the crypt epithelial cells. Crypts were looked for systematically between the surface epithelium and the muscularis mucosae and at least 200 crypt cells were counted. In the same specimens the densities in the epithelium of cells having $\alpha / \beta$ or $\gamma / \delta \mathrm{T}$ cell receptors, and CD3, CD4, and CD8 antigens had been counted earlier. ${ }^{13}$

Monoclonal antibodies - to constant fragments of HLA-DR and -DP chains purchased from Becton Dickinson (Mountain View, CA, USA) were used at a dilution of $1: 1000$ and 1:40, respectively. Anti-DQ monoclonal antibody (Serotec Ltd, Oxford, England) reacting with a monomorphic determinant present on all HLADQ molecules ${ }^{17}$ was used at a dilution of 1:400. Anti-IL2 receptor antibody (anti CD25, Becton Dickinson) was diluted 1:20. Monoclonal anti- body Ki67 (DAKO-PC, Dakopatts, Glostrup, Denmark) recognising a nuclear antigen present only in proliferating cells ${ }^{18}$ was used at a dilution of $1: 10$.

\section{GENETIC MARKERS}

DQA and DQB genes were analysed by restriction fragment length polymorphism according to the protocol designed by the 10th International Histocompatibility Workshop, ${ }^{19}$ using the specific c-DNA probes distributed by the workshop. The restriction enzymes TaqI and PstI were informative for the $\mathrm{DQA} 1$ and $\mathrm{DQB} 1$ genes respectively. Recently, a DQA restriction fragment, $4.8 \mathrm{~kb}$ in size, was found to detect $97 \%$ of Finnish coeliac disease patients and $27 \%$ of controls. PstI restriction fragment length polymorphism analysis of the DQB gene again showed a $100 \%$ association with coeliac disease, and only $25 \%$ of the controls had this $5 \cdot 2 \mathrm{~kb}$ gene marker fragment. ${ }^{20}$

\section{STATISTICAL ANALYSIS}

Of the specimens from family members and from controls, the proportion in which staining of the epithelium was either absent/weak $(0-1)$ or moderate/strong (2-3) with HLA class II antibodies was compared by contingency table calculation with a personal computer program (Statgraphics). The same staining intensities of the epithelium and the presence of CD25+ cells in the epithelium were cross tabulated with the

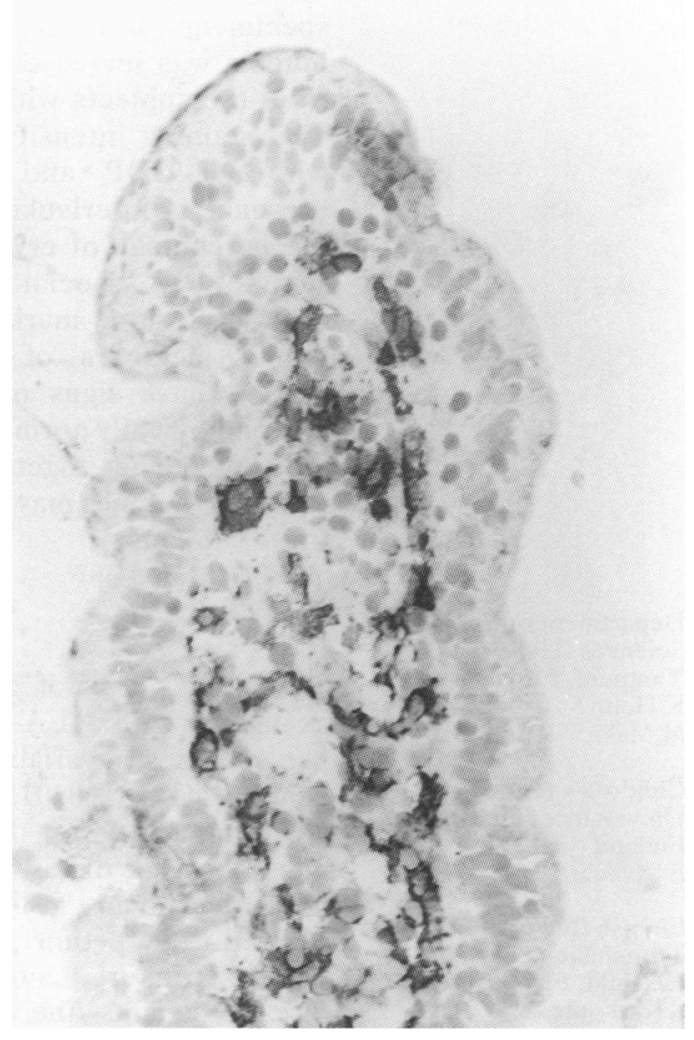

Figure 1: Specimen with normal villous structure from a relative having no coeliac disease marker $D Q$ genes, stained with antibody to HLA-DP. Surface of epithelial cells on the tip of the villus show staining, its intensity was graded as 1 similar to most of controls. In addition, there are positive cells in the lamina propria of the villus. Original magnification $\times 25$. 
TABLE I Proportion of jejunal specimens showing a strong or moderate intensity of epithelial staining with HLA-DP and HLA-DR antibodies. Comparison between controls and family members of coeliac disease patients subdivided on the basis of the morphology of the jejunum and the number of coeliac disease marker $D Q$ genes

\begin{tabular}{|c|c|c|c|c|}
\hline \multirow[b]{2}{*}{ Group } & \multicolumn{2}{|l|}{ DP antibody } & \multicolumn{2}{|l|}{ DR antibody } \\
\hline & $\begin{array}{l}\text { Strong or } \\
\text { moderate }(2-3), \\
n(\%)\end{array}$ & $\begin{array}{l}p^{\star} \\
\text { Compared } \\
\text { with controls }\end{array}$ & $\begin{array}{l}\text { Strong or } \\
\text { moderate }(2-3), \\
n(\%)\end{array}$ & $\begin{array}{l}p^{\star} \\
\text { Compared } \\
\text { with controls }\end{array}$ \\
\hline All family members & $38 / 74(51)$ & 0.004 & $41 / 73(55)$ & 0.05 \\
\hline $\begin{array}{l}\text { Family members witn silent coeliac } \\
\text { disease }\end{array}$ & $11 / 11(100)$ & 0.00001 & $11 / 11(100)$ & 0.002 \\
\hline $\begin{array}{l}\text { Family members with normal } \\
\text { jejunum } \\
\text { Family members with } 0 \text { or } 1 \text { marker }\end{array}$ & $27 / 63(43)$ & 0.03 & $30 / 62(48)$ & $0 \cdot 2$ \\
\hline $\begin{array}{l}\text { DQ genes } \\
\text { Family members with 2-4 marker }\end{array}$ & $9 / 29(31)$ & $0 \cdot 2$ & $13 / 29(45)$ & $0 \cdot 3$ \\
\hline $\begin{array}{l}\text { DQ genes } \\
\text { Controls }\end{array}$ & $\begin{array}{r}29 / 45(64) \\
3 / 19(15)\end{array}$ & 0.0004 & $\begin{array}{r}28 / 44(63) \\
6 / 19(32)\end{array}$ & $0 \cdot 2$ \\
\hline
\end{tabular}

${ }^{\star}$ By Fisher's exact test.

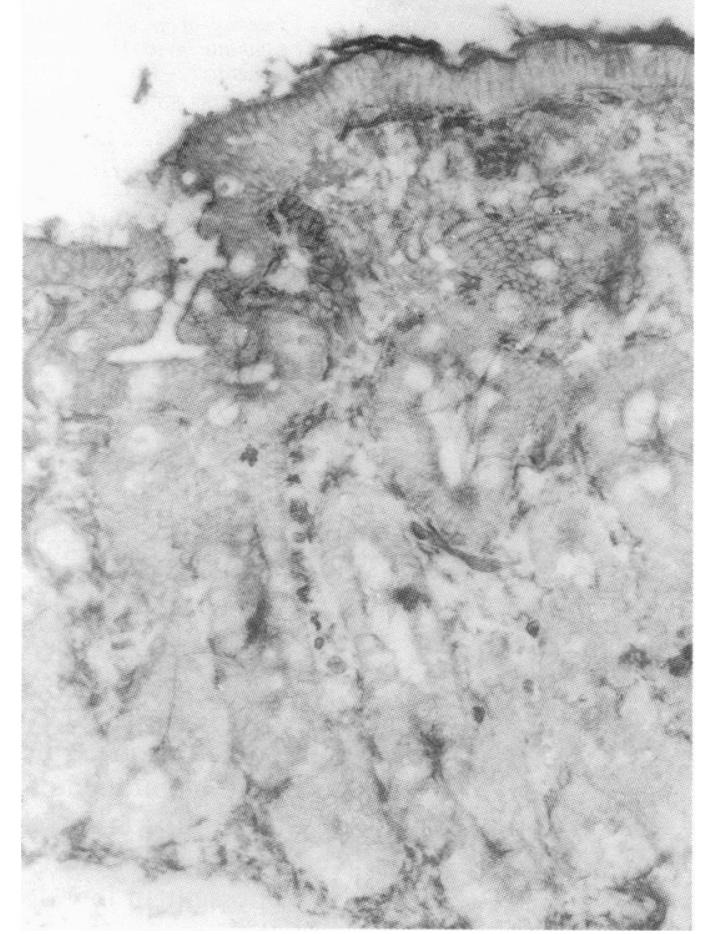

Figure 3: Specimen from a patient with silent coeliac disease stained with HLA-DP antibody. Not only the surface membranes of the epithelial cells, but also the intercellular and basal membranes of the cells are stained. The crypt epithelium also shows strong staining (grade 3). Original magnification $\times 10$.

stronger and more widely distributed on the villi than in the controls (Fig 2). In specimens with normal morphology, HLA-DP antibodies sometimes stained the epithelium to the base of the villi (Fig 2), but staining of the crypts was never seen. In the specimens from family members with silent coeliac disease, the crypts were also stained (Fig 3). Strong or moderate staining of the epithelium was more often seen in the specimens of family members of coeliac disease patients than in those from controls (Table I). This difference was more pronounced when relatives with two to four CDM DQ genes were compared with controls (Table I).

In the same way, staining with HLA-DR antibodies was stronger in the specimens from family members than in those from controls (Table I). The positive staining was extended to the crypts in eight specimens with normal morphology taken from family members. The HLADQ antibodies did not stain any epithelial structures in any of the biopsy specimens.

The intensity of HLA-DP and -DR staining was positively associated particularly with the number of CDM DQB genes (Table II); the association to the dose of CDM DQ genes $(0-1$ or 2-4) was significant only with the intensity of HLA-DP staining (Table II). The associations with the number of DQA CDM genes $(0-2)$ were not significant (Table II).

Additionally, the HLA-DP staining intensity in the specimens from family members with normal jejunum, was also significantly associated with the dose of CDM genes $(0-1$ or $2-4)$,
Weak staining with HLA-DP antibodies (Fig 1) was seen more rarely in specimens from family members with normal jejunum than in controls (Table I). In many of the specimens from family members, even those with normal jejunal structure, the epithelial staining for HLA-DP was

number of CDM DQA and DQB genes (0-2),
and with the dose of both these genes, classified staining intensities of HLA-DP and -DR in the or absence of CD25+ cells, with the percentages
of dividing crypt cells and with densities of cells epithelium were looked for with one way analysis of variance, using a non-parametric procedure,

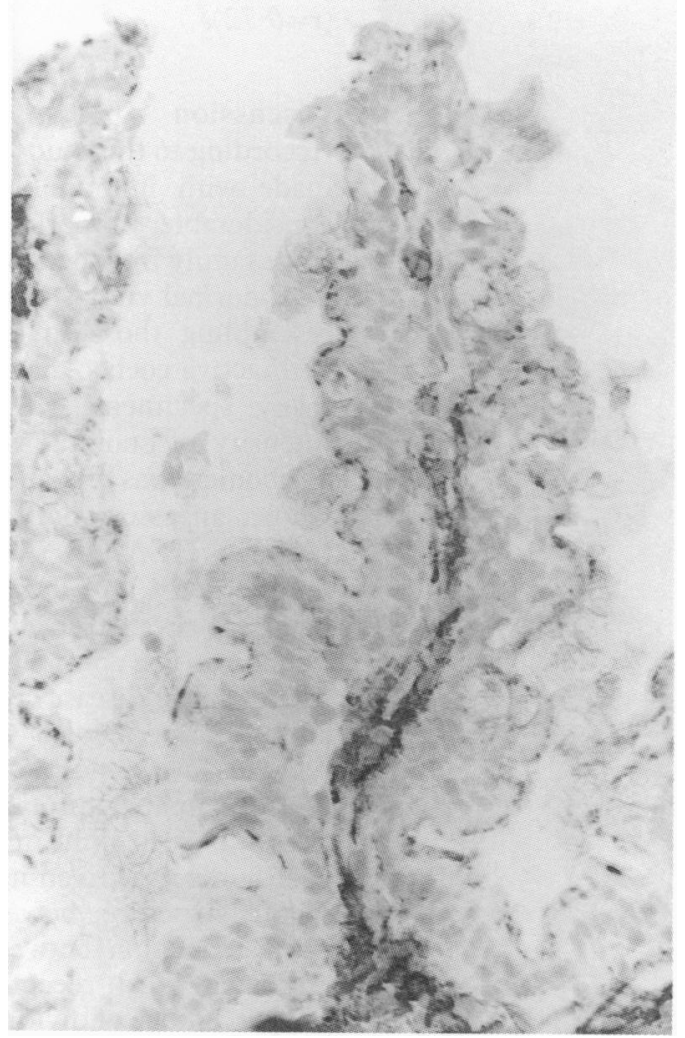
epithelium (graded from 0 to 3 ), or the presence
Figure 2: Specimen from a $D Q B$ coeliac disease marker genes, stained with $H L A$ DP antibody. Positive staining (grade 2) of the epithelial cells is seen in a villus with normal structure extending to the base of the villus. Original magnification $\times 10$ 
TABLE II - Association between the intensity of staining of the epithelial cells with antibodies to $H L A$ class II antigens, the CD25+ cells in the epithelium, the percentage of Ki67+ crypt epithelial cells, and the number of coeliac disease marker $D Q A$ and $D Q B$ genes, and the dose of these genes $(0-1$ or $2-4)$

\begin{tabular}{|c|c|c|c|c|}
\hline & \multicolumn{2}{|c|}{$\begin{array}{l}\text { Intensity of epithelial staining: } \\
\text { weaklabsent }(0-1) \text { or strong/ } \\
\text { moderate }(2-3)\end{array}$} & \multirow{2}{*}{$\begin{array}{l}\text { CD25 }{ }^{+} \text {cells in } \\
\text { the epithelium } \\
\begin{array}{l}\text { Absent or } \\
\text { present } p^{\star}\end{array}\end{array}$} & \multirow{2}{*}{$\begin{array}{l}\begin{array}{l}\text { Ki67+ } \\
\text { epithelial } \\
\text { cells }\end{array} \\
\% \text { of cryp } \\
\text { cells pt }\end{array}$} \\
\hline & $\begin{array}{l}\text { With } \\
\text { antibodies to } \\
H L A-D P, p^{\star}\end{array}$ & $\begin{array}{l}\text { With } \\
\text { antibodies to } \\
H L A-D R, p^{\star}\end{array}$ & & \\
\hline $\begin{array}{l}\text { No of DQA marker genes }(0-2) \\
\text { No of DQB marker genes }(0-2)\end{array}$ & $\begin{array}{l}0.1 \\
0.009\end{array}$ & $\begin{array}{l}0.4 \\
0.05\end{array}$ & $\begin{array}{l}0 \cdot 1 \\
0 \cdot 02\end{array}$ & $\begin{array}{l}0 \cdot 2 \\
0.02\end{array}$ \\
\hline $\begin{array}{l}\text { Dose of DQA and DQB marker genes } \\
(0-1 \text { or } 2-4)\end{array}$ & 0.009 & $0 \cdot 2$ & 0.04 & 0.08 \\
\hline
\end{tabular}

${ }^{\star} \mathrm{B} \chi^{2}$ test, + Kruskal-Wallis test.

\section{DIVIDING (Ki67+) EPITHELIAL CELLS IN THE} CRYPTS

The percentage of crypt cells staining with $\mathrm{Ki} 67$ antibodies was similar in controls (median 18\%) and family members of patients with coeliac disease $(13 \%)$. The patients with silent coeliac disease had a significantly higher percentage of Ki67+ crypt cells (36\%) than the controls with normal villous structure $(\mathrm{p}<0.00001$ MannWhitney U test).

In the whole group, the percentage of dividing crypt cells was significantly associated only with the number of CDM DQB genes (Table II), but not with the number of DQA genes or the sum of these genes.

$p=0 \cdot 04$. The lamina propria of every jejunal biopsy specimen contained cells staining positively with all three HLA class II antibodies and there was also extracellular staining with antibodies of each type (Figs 1-3).

INTERLEUKIN-2 RECEPTOR POSITIVE CELLS With the peroxidase methods, positive cells were seen in the epithelia of 18 specimens. The more sensitive phosphatase method showed positive cells in an additional 14 specimens. Positive cells were present in low density in both the surface and the crypts (Fig 4). All the eight examined specimens with villous atrophy contained CD25+ cells. None of the controls had CD25+ cells in the epithelium, while 24 of 54 family members with normal jejunum had these cells $(p=0.003)$. The whole dose of CDM DQ genes $(0-1$ or $2-4)$ and the number of similar DQB genes were associated with the presence of CD25+cells (Table II), whereas the numbers of DQA genes showed no such relation.

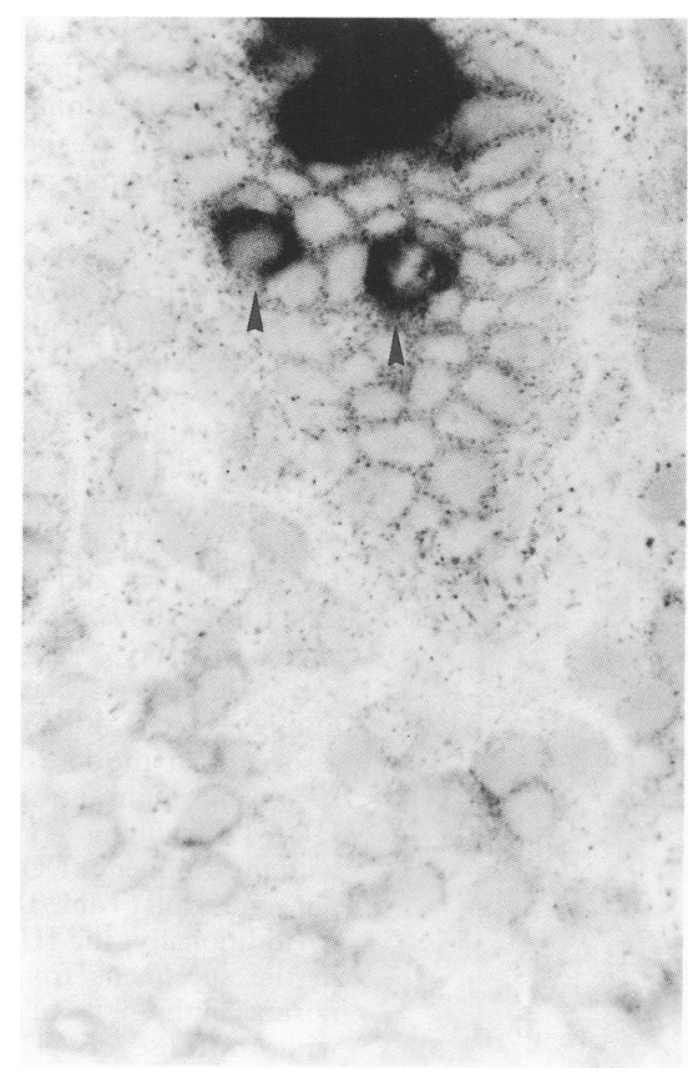

ASSOCIATIONS BETWEEN THE MEASUREMENTS

The intensity of epithelial DP staining showed a significant association with the density of cells bearing $T$ cell receptors $\alpha / \beta(p=0.01)$ and $\gamma / \delta$ $(p=0.0003)$ in the epithelium. For DR staining, the associations with only the $T$ cell receptor $\alpha / \beta+$ cells was significant $(p=0 \cdot 04)$.

In the group as a whole the association between the intensity of HLA-DP staining and the presence of $\mathrm{CD} 25+$ cells was significant in specimens with normal morphology $(p=0.001)$. The presence of CD25+ cells was associated with the density of $\mathrm{T}$ cell receptor $\gamma / \delta+(p=0.01)$ and $\alpha / \beta+(p=0.009)$ intraepithelial cells.

The percentage of proliferating crypt cells was significantly associated with the density of $\gamma / \delta \mathrm{T}$ cell receptor positive cells in the epithelium both in the group as a whole $(\mathrm{p}<0.00001, r=0.65)$ and also in the 57 specimens with normal structure $(p=0.02)$. The correlation between the percentage of crypt cells in mitosis and the density of $\mathrm{T}$ cell receptor $\gamma / \delta$ positive cells was closest in persons having two or more CDM DQ genes $(r=0 \cdot 72)$.

\section{Discussion}

According to this study and our previous study ${ }^{13}$ made with immunohistochemical methods, a considerable proportion of jejunal specimens from family members of coeliac disease patients with normal villous structure have had changes resembling those in specimens from patients with active coeliac disease. In the epithelium of many specimens with normal structure the intensity of staining with HLA-DP and -DR antibodies was enhanced. In the group as a whole, an association was particularly evident between HLA-DP staining intensity and the number of CDM DQ genes, this association being seen even in specimens with normal villous structure. The epithelium of all the patients with silent coeliac disease contained activated $T$ cells and these were also present in many of the relatives with normal villous structure. An increase in the mitotic rate of crypt epithelial cells was seen only in the patients with silent coeliac disease. Even in specimens with normal villous structure, however, there was a significant association between the density of intraepithelial T cell receptor $\gamma / \delta$ positive cells and the percentage of dividing crypt cells. $(p=0.007)$. This association was also significant
Figure 4. Two interleukin-2 receptor positive cells, shown by arrowheads, in a crypt of a jejunal specimen from a family member with silent coeliac disease having one $D Q A$ and $D Q B$ coeliac disease marker gene. 
In coeliac disease patients, the intensity of expression of the HLA-DR antigen in the intestines of patients with coeliac disease has been shown to be gluten dependent. ${ }^{21-23}$ Gluten may stimulate the expression of these antigens either directly, as has been shown in spleen cells with hen egg lysozyme, ${ }^{24}$ or by initiating inflammation of $\gamma$-interferon secretion..$^{25}$ In this study, the HLA-DP staining intensity was associated particularly with other indices of inflammation, such as the density of $\mathrm{T}$ cells in the epithelium, and especially with that of cells bearing $\gamma / \delta T$ cell receptor. This cell population may not, however, be gluten dependent, and is so far the only constant change able to be seen in the intestines of patients with coeliac disease. ${ }^{27}$ The expression of disease associated DQ molecules on epithelial cells of the jejunum would offer a logical explanation for the close association between coeliac disease and HLADQ genes. ${ }^{122}$ In agreement with most earlier studies, ${ }^{28-30}$ however, which report infrequent expression, if any, of the HLA-DQ antigen in the epithelium of normal and coeliac jejunal mucosae, we saw expression of DQ antigens only in the lamina propria. It has been speculated that the important role of HLA-DQ molecules is to induce elimination of autoreactive $T$ cells during fetal life, but certain DQ phenotypes permit survival of such clones. ${ }^{31}$ It may be argued that the abundant $\gamma / \delta \mathrm{T}$ cell receptor positive cells in the epithelium of patients with coeliac disease are such remnants.

In active coeliac disease the crypt compartment is greatly enhanced and mitotic figures are seen in an increased proportion of crypt cells. ${ }^{32}$ In this study the percentage of cells in mitosis was estimated with a monoclonal antibody recognising a proliferation related antigen associated with the nuclear matrix. ${ }^{18}$ The numbers of crypt cells in mitosis were higher in the cases with silent coeliac disease than in the controls. No increase in the proportion of cells in mitosis was seen in specimens from family members of coeliac disease patients having normal villous structure. The control series may not have been the best possible, however, because it consisted of patients having endoscopical examination of the upper gastrointestinal tract because of intestinal complaints. Therefore the site where the biopsy specimens were taken were slightly different. A part of the control specimens were from the duodenum, while all specimens from family members were taken from the jejunum with a capsule. Even though the controls specimens were found to be morphologically normal, low grade inflammation, possibly increasing the mitotic rate, ${ }^{33}$ could not be excluded. The percentage of cells in mitosis was associated with markers of inflammation, such as the staining intensity of epithelial cells with HLA-DP antibodies. Interestingly, the association was closest with the density of $\gamma / \delta \mathrm{T}$ cell receptor positive cells in the epithelium; this association was significant even in specimens with normal villous structure. The association would fit with the proposed role of $\gamma / \delta \mathrm{T}$ cell receptor positive cells in eliminating damaged epithelial cells. ${ }^{34}$

In humans, activated $T$ cells have been reported in the epithelium of only one patient with chronic rejection of a jejunal transplant. ${ }^{35}$ In tissue culture of fetal intestine, activated $T$ cells have been associated with the development of villous atrophy. ${ }^{36}$ They have been seen in the lamina propria of patients with coeliac disease as well. ${ }^{37}$ In earlier studies, CD25+ cells have not been seen in the epithelium of jejunal specimens from patients with coeliac disease. The variability in finding these cells is probably due to the low density of interleukin-2 receptors expressed by intraepithelial lymphocytes. ${ }^{38}$ When we increased the sensitivity of the staining, a higher proportion of specimens showed CD25+ cells.

We infer that in many family members of patients with coeliac disease there is a low grade of inflammation in the jejunum, even if the specimens seem morphologically normal. In the group as a whole, the degree of inflammation is associated with the dose of CDM HLA-DQ genes and in most instances with $\mathrm{DQB}$ genes.

Supported by the Sigrid Juselius Foundation, Medical Research Council, Academy of Finland, University of Tampere, University of Helsinki, and the Emil Aaltonen Foundation. The authors thank Terttu Louhio for skillful technical assistance.

1 Roep BO, Bontrop RE, Pena AS, van Eggermond MCJA, van Rood JJ, Giphart MJ. An HLA-DQ alpha allele identified at DNA and protein level is strongly associate

2 Sollid LM, Markussen G, Ek J, Gjerde H, Vartdal F, Thorsby E. Evidence for a primary association of celiac disease to a particular HLA-DQ alpha/beta heterodimer. $\mathcal{F}$ Exp Med 1989; 169: 345-50.

3 Marsh MN. Gluten, major histocompatibility complex, and the small intestine - A molecular and immunobiologic approach to the spectrum of gluten sensitivity (celiac sprue). Gastroenterology 1992; 102: 330-54.

4 Weinstein WM. Latent celiac sprue. Gastroenterology 1974; 66: 489-93.

5 Ferguson A, Blackwell JN, Barnetson RStC. Effects of additional dietary gluten on the small-intestinal mucosa of additional dietary gluten on the small-intestinal mucosa of volunt F Gastroenterol 1987; 22: 543-9.

6 Doherty M, Barry RE. Gluten-induced mucosal changes in subjects without overt small-bowel disease. Lancet 1981; i: $517-20$

7 Mäki M, Holm K, Koskimies S, Hällström O, Visakorpi J. Normal small bowel biopsy followed by coeliac disease. Arch Dis Child 1990; 65: 1137-41.

8 Kosnai I, Karpati S, Savilahti E, Verkasalo M, Bucsky P, Török E. Gluten challenge in children with dermatitis herpetiformis: A clinical, morphological and immunohistological study. Gut 1986; 27: 1464-70.

9 O'Mahony S, Vestey JP, Ferguson A. Similarities in intestinal humoral immunity in dermatitis herpetiformis without humoral immunity in dermatitis herpetiformis without enteropat $1487-90$.

10 Marsh MN. Studies of intestinal lymphoid tissue. XV. Histopathologic features suggestive of cell-mediated reactivity in jejunal mucosae of patients with dermatitis herpetiformis. Virchows Arch [A] 1989; 416: 125-32.

1 Marsh MN, Bjarnason I, Shaw J, Ellis A, Baker R, Peters TJ. Studies of intestinal lymphoid tissue. XIV-HLA status, mucosal morphology, permeability and epithelial lymphocyte populations in first degree relatives of patients with coeliac disease. Gut 1990; 31: 32-6.

12 Holm K. Correlation of HLA-DR alleles to jejunal mucosal morphology in healthy first-degree relatives of coeliac disease patients. Eur f Gastroenterol Hepatol 1993; 5: 35-9.

13 Holm K, Mäki M, Savilahti E, Lipsanen V, Laippala P, Koskimies S. Dose effect of DQA and DQB genes on the density of intraepithelial gamma/delta $T$ cell receptor beardensity of intraepithelial gamma/delta T cell receptor bearing lymphocytes in healthy first-degree re
disease patients. Lancet 1992; 339: 1500-3.

14 Mäki M, Holm K, Collin P, Savilahti E. Increase of gamma/ delta $T$ cell receptor bearing lymphocytes in normal small bowel mucosa in latent coeliac disease. Gut 1991; 32: 1412-4.

15 Mäki M, Holm K, Lipsanen V, Hällström $O$, Viander $M$, Collin P, et al. Serological markers and HLA genes among healthy first-degree relatives of patients with coeliac disease. Lancet 1991; 338: 1350-3.

16 Spencer J, MacDonald TT, Diss TC, Walker-Smith JA, Ciclitira PJ, Isaacson PG. Changes in intraepithaliel lymphocyte subpopulations in coeliac disease and enteropathy cyte subpopulations in coeliac disease and enteropathy associated T cell lymphoma (ma
intestine). Gut $1989 ; 30: 339-46$.

17 Spits H, Borst J, Giphart M, Coligan J, Terhorst C, De Vries JE. HLA-DC antigen can serve as recognition elements for JE. HLA-DC antigen can serve as recognition elements for 299-304.

18 Gerdes J, Lemke H, Baisch H, Wacker H-H, Schwab U, Stein $\mathrm{H}$. Cell cycle analysis of a cell proliferation-associated 
human nuclear antigen defined by the monoclonal antibody Ki67. F Immunol 1984; 133: 1710-5.

19 Dupont B. Immunology of HLA. II. Immunogenetics and histocompatibility. New York: Springer, 1989.

20 Koskimies S, Lipsanen V, Mäki M, Visakorpi J. HLA and coeliac disease, a Finnish family study. In: Mearin ML, Mulder CJJ, eds. Coeliac disease. 40 years gluten-free. Dordrecht/Boston/London: Kluwer Academic, 1991: 9-13.

21 Scott H, Brandtzaeg P, Solheim BG, Thorsby E. Relation between HLA-DR-like antigens and secretory componen (SC) in jejunal epithelium of patients with coeliac disease or dermatits herpetiformis. Clin Exp Immunol 1981; 44 233-8.

22 Arnaud-Battandier F, Cerf-Bensussan N, Amsellem R, Schmitz J. Increased HLA-DR expression by enterocytes in children with celiac disease. Gastroenterology 1986; 91 : 1206-12.

23 Marley NJ, Macartney JC, Ciclitira PJ. HLA-DR, DP and DQ expression in the small intestine of patients with coeliac DQ expression in the small intestine of patient

24 Germain RN, Hendrix LR. MHC class-II structure, occupancy and surface expression determined by postendoplasmic reticulum antigen binding. Nature 1991; 353 134-9.

25 Cerf-Bensussan N, Schneeberger EE, Bhan AK. Immunohistologic and immunoelectron microscopic characterization of the mucosal lymphocytes of human small intestine by the use of monoclonal antibodies. F Immunol 1983; 130: 2615-22.

26 Spencer J, Finn T, Isaacson PG. Expression of HLA-DR antigens on epithelium associated with lymphoid tissue in the human gastrointestinal trace Gut 1986;27: 153-7.

27 Savilahti E, Arato A, Verkasalo M. Intestinal gamma/delta receptor-bearing $\mathrm{T}$ lymphocytes in celiac disease and inflammatory bowel diseases in children. Constant increase in

28 Kelly J, Weir DG, Feighery C. Differential expression of
HLA-DR gene products in the normal and coeliac small bowel. Tissue Antigens 1988; 29: 151-60.

29 Mayer L Eisentardt D, Salomon P, Bauer W, Plous R Piccinini L. Expression of class II molecules on intestinal epithelial cells in humans. Differences between normal and epithelial cells in humans. Differences between normal and inflam.

30 Schweizer JJ, Mearin ML, Pena AS, Offerhaus GJA, Dree EJ, Roep BO, et al. Expression of HLA-DQ antigens in the small-intestinal mucosa of patients with coeliac disease. Scand 7 Gastroenterol 1991; 26: 605-10.

31 Altmann DM, Sansom D, Marsh SGE. What is the basis for HLA-DO associations with autoimmune disease. Immunol Today 1991; 12: 267-70.

32 Wright N, Watson A, Morley A, Appleton D, Marks J. Cell kinetics in flat (avillous) mucosa of the human small intestine. Gut 1973; 14: 701-10.

33 De Silva HJ, Millard PR, Kettlewell M, Mortensen NJ, Prince C, Jewell DP. Mucosal characteristics of pelvic ileal pouches. Gut 1991; 32: 61-5.

34 Janeway CA Jr, Jones B, Hayday A. Specificity and function of T cells bearing gammadelta receptors. Immunol Today 1988 9: $73-6$

35 Cerf-Bensussan N, Brousse N, Jarry A, Goulet O, Revillon Y, Ricour C, et al. Role of in vivo activated $T$ cells in the mechanisms of villous atrophy in humans: study of allograft rejection. Digestion 1990; 46 (suppl 2): 297-301.

36 MacDonald TT, Spencer J. Evidence that activated mucosal T cells play a role in the pathogenesis of enteropathy in human small intestine. 7 Exp Med 1988; 167: 1341-50.

37 Kelly J, O'Farrelly C, O'Mahony C, Weir DG, Feighery C. Immunoperoxidase demonstration of the cellular composition of the normal and coeliac small bowel. Clin Exp Immunol 1987; 68: 177-88.

38 Ebert EC. Proliferative responses of human intraepithelia lymphocytes to various T-cell stimuli. Gastroenterology 1989; 97: 1372-81. 